Nota Científica

(Short communication)

\title{
NEW LOCALITY OF THE ENDANGERED SIERRA MADRE SPARROW (XENOSPIZA BAILEYI) FROM THE STATE OF DURANGO, MEXICO, AND RECOMMENDATIONS FOR ITS CONSERVATION
}

\author{
NUEVA LOCALIDAD DEL GORRION SERRANO EN PELIGRO DE EXTINCIÓN \\ (XENOSPIZA BAILEYI) EN EL ESTADO DE DURANGO, MÉXICO, Y RECOMENDACIONES \\ PARA SU CONSERVACIÓN
}

\author{
JosÉ HUGo MARTÍNEZ-GUERRERO ${ }^{1}$, JORGE NOCEDAL ${ }^{2}$, DANIEL SIERRA-FRANCO ${ }^{3}$, SAMUEL IGNACIO \\ ARROYO-ARROYO ${ }^{4}$, MARTÍN EMILIO PEREDA-SOLIÍs ${ }^{5 *}$ \\ ${ }^{1}$ Facultad de Medicina Veterinaria y Zootecnia, Universidad Juárez del Estado de Durango, 34000 Durango, Dgo., México. \\ <che_hugo1@hotmail.com> \\ 2 PH Consultores Ambientales, 34217 Durango, Dgo., México. <nocedal.j@gmail.com> \\ ${ }^{3}$ Facultad de Medicina Veterinaria y Zootecnia, Universidad Juárez del Estado de Durango, 34000 Durango, Dgo., México. \\ $<$ Dan_1015@hotmail.com> \\ ${ }^{4}$ Alumno del Programa de Doctorado Institucional en Ciencias Agropecuarias y Forestales, Universidad Juárez del Estado de \\ Durango, 34000 Durango, Dgo., México. <Nacho220719@gmail.com> \\ ${ }^{5}$ Facultad de Medicina Veterinaria y Zootecnia, Universidad Juárez del Estado de Durango, 34000 Durango, Dgo., México. \\ $<$ mepereda@ujed.mx> \\ *Autor de correspondencia: <mepereda@ujed.mx>
}

Recibido: 29/08/2017; aceptado: 24/05/2018; publicado en línea: 26/10/2018

Editor responsable: Ricardo Rodríguez Estrella

Martínez-Guerrero, J. H., Nocedal, J., Sierra-Franco, D., Arroyo-Arroyo, S. I., Pereda-Solís, M. E. (2018) New Locality of the endangered Sierra Madre Sparrow (Xenospiza Baileyi) from the State of Durango, Mexico, and recommendations for its conservation. Acta Zoológica Mexicana (nueva serie), 34, 1-6. DOI: https://doi.org/10.21829/azm.2018.3412115

\begin{abstract}
The Sierra Madre Sparrow (Xenospiza baileyi) is an endemic species of Mexico that is threatened with extinction. Its distribution is reported in two areas: One in the Transvolcanic Belt of central Mexico (La Cima) near Mexico City and the other in the Sierra Madre Occidental in northwestern Mexico (Ejido Ojo de Agua El Cazador) near the city of Durango, in the state of Durango. The habitat is the same in these two areas, and consists of sub-alpine grassland that is located in shallow valleys or shallows. In our case, "El Bajío la Cantera" of approximately 55 hectares, is mostly used in rainfed agriculture, protected from livestock grazing with wire fences, which in turn represents protection for remnants of grassland where they are the birds. "El Bajío la Cantera" belongs to Ejido 12 de Mayo, Municipality of San Dimas, Durango, where 28 males were detected singing along a 500 meter transect. This finding represents the population of the healthiest Sierra Madre Sparrow currently known, so it would be necessary to document their population trend over time. This information can help to evaluate and propose the creation of a special protection area for the species that involves joint government actions and ejidatarios tending to conserve the habitat during the reproductive season in order to increase and / or maintain the size of the population.
\end{abstract}

Key words: Xenospiza baileyi; Sierra Madre Sparrow; endemic species; endangered species; Durango; new locality 
Martínez-Guerrero, J. H., Nocedal, J., Sierra-Franco, D., Arroyo-Arroyo, S. I., Pereda-Solís, M. E. (2018) Nueva localidad del gorrión serrano en peligro de extinción (Xenospiza baileyi) en el estado de Durango, México, y recomendaciones para su conservación. Acta Zoológica Mexicana (nueva serie), 34, 1-6. DOI: https://doi.org/10.21829/azm.2018.3412115

RESUMEN. El gorrión serrano (Xenospiza baileyi) es una especie endémica de México y se encuentra en peligro de extinción. Su distribución se reporta en dos áreas: Una en el Cinturón Transvolcánico del centro de México (La Cima) cerca de la Ciudad de México y la otra en la Sierra Madre Occidental en el noroeste de México (Ejido Ojo de Agua El Cazador) cerca de la ciudad de Durango, en el estado de Durango. El hábitat es el mismo en estas dos áreas, y consiste en pastizales amacollados subalpinos que se localizan en valles poco profundos o bajíos. En nuestro caso, “El Bajío la Cantera” de aproximadamente 55 Has de superficie, es usado mayormente en la agricultura de temporal, protegida del pastoreo del ganado con cerco de alambre, que a su vez representa protección para los remanentes de pastizal amacollado donde están las aves. "El Bajío la Cantera” pertenece al Ejido 12 de Mayo, Municipio de San Dimas, Durango, donde se detectaron 28 machos cantando a lo largo de un transecto de 500 metros. Este hallazgo representa la población de Gorrión serrano más saludable actualmente conocida, por lo que sería necesario documentar su tendencia poblacional a través del tiempo. Esta información puede ayudar a evaluar y proponer la creación de un área de protección especial para la especie que involucre acciones conjuntas de gobierno y ejidatarios tendientes a conservar el hábitat durante la época reproductiva para lograr aumentar y/o mantener el tamaño de la población.

Palabras clave: Xenospiza baileyi; gorrión serrano; especie endémica; especie en peligro de extinción; Durango; nueva localidad

The Sierra Madre Sparrow (Xenospiza baileyi) was described by Bangs (1931), based on specimens collected at Bolaños, Jalisco (Pitelka, 1947). Recent molecular studies have shown that the genus Xenospiza is closest to Melospiza, in the clade of "grassland sparrows" as identified by Klicka \& Spellman (2007). The Sierra Madre Sparrow (SMSP) belongs to the newly diagnosed Family Passerellidae, based on recent studies of molecular phylogeny (Klicka et al., 2014). The SMSP is endemic to Mexico, and its actual distribution is restricted to two disjunct ranges, approximately $800 \mathrm{~km}$ apart (Oliveras de Ita \& Gómez de Silva, 2002; Oliveras de Ita \& Rojas-Soto, 2006; Gallegos, 2014): one in the Transvolcanic Belt of Central Mexico (La Cima) near Mexico City and the other one in the Sierra Madre Occidental (Ejido Ojo de Agua El Cazador), near the city of Durango. The SMSP is an endangered species of importance to Mexico (SEMARNAT, 2010), and also considered endangered at the international level (IUCN, 2018). The habitat where the SMSP has been recorded is subalpine bunch grasslands composed of varied species of Mulhenbergia, Festuca and Stipa grasses (Oliveras de Ita \& Gómez de Silva, 2002; Oliveras de Ita \& Rojas-Soto, 2006; Cabrera-García et al., 2006), located at the bottom of shallow valleys or "bajíos", usually with small streams running through and surrounded by pine forests. In general, these "bajíos" are exposed to changes in land use for agriculture and grazing by cattle (Rojas-Soto et al., 2008). In Durango, these pine forests are composed primarily of Pinus cooperi, with a ground cover of bunch grass Mulhenbergia macroura (Gonzalez-Elizondo et al., 2007). Oliveras de Ita \& Gómez de Silva (2002), found and described a new locality for SMSP in the Estado de México, not far from the only locality know in central Mexico (La Cima). Later, during a survey in search of the SMSP at historical localities, where specimens were collected in the states of Durango, Jalisco and Zacatecas, they found and described the only known locality in Durango at Ejido Ojo de Agua El Cazador (Oliveras de Ita \& Rojas-Soto, 2006). Two of us (JHMG, JN) visited the study area and encountered the first singing male, we decided to run a transect just to have a rough idea of population size. It should be remarked that we did not use any records from the eBird database as some are not reliable, especially those of this cryptic sparrow during the non- 
breeding season. For example, there is an incorrect record in the database for this species in Durango, right in the middle of the city of El Salto, where we know it does not occur as there are no grasslands appropriate for their occurrence (eBird: accessed on October 2, 2016). Another questioned record is at El Magueyal (eBird: accessed on October 2, 2016), located within the same municipality as our new record, but with an attached species list that suggests the survey was carried out in habitat inappropriate for the SMSP, especially during the breeding season (August 2007). All the other Durango records in the eBird database are related to Ejido Ojo de Agua del Cazador (eBird: accessed on October 2, 2016). Finally, there is a very unlikely record at Sierra de Organos (eBird: accessed on October 2, 2016), located at the border of the states of Durango and Zacatecas, where the habitat does not match the upland bunch grassland habitat required of the SMSP, but also the date of the record is quite wrong (February 2007). We warn to use, very carefully, the so-called citizen's science records when dealing with "rare" or "endemic" species, seemingly used by some birders to enlarge their life lists.

Methods. Study area. A new locality for the SMSP is the Ejido 12 de Mayo, San Dimas Municipality, Durango (Fig. 1). The habitat is a small shallow valley or "bajío" known locally as "El Bajío la Cantera", with an area of $55 \mathrm{ha}$, at an elevation of 2,349 $\mathrm{m}$ and surrounded by pine ( $P$. cooperi) forests (coordinates $24^{\circ} 25.4^{\prime} \mathrm{N}$ and $105^{\circ} 27.4^{\prime} \mathrm{W}$ ). Actual land use is non-irrigated agriculture with some patches of bunch grassland comprised of mostly, "pajón” grass (Mulhenbergia macroura). Two of us (JHMG, JN) surveyed a $500 \mathrm{~m}$ transect through the grassland with the help of a GPS (Garmin ${ }^{\circledR}$ Etrex) and binoculars (Carl Zeiss ${ }^{\circledR}$ Legend 10X42). We also took some photographs (Canon ${ }^{\circledR}$ EOS 7D Mark II model with a Sigma ${ }^{\circledR}$ 150-500 mm telephoto lens) to support our ID (Fig. 2). In addition, we all know the species song quite well.

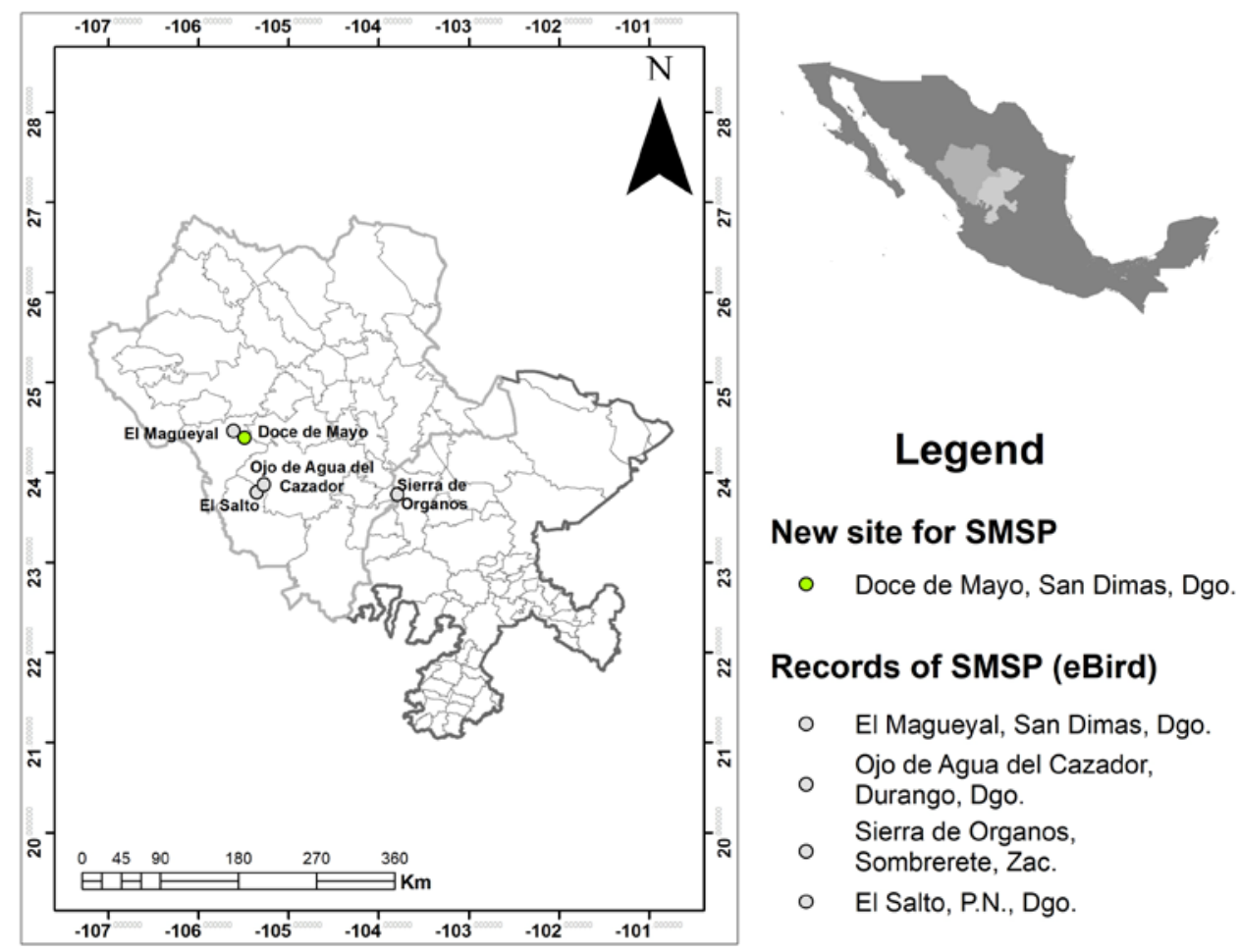

Figure 1. New locality of the Sierra Madre Sparrow (SMSP) at "El Bajío la Cantera”, Ejido 12 de Mayo, San Dimas Municipality, Durango, México. On the upper right corner, a map of Mexico showing the location of the state of Durango. 
Results and discussion. We recorded a total of 28 singing male SMSP along the 500-m transect through the bottom of the "bajío". This number of singing males shows that this site must be managed and protected as this is the healthiest population currently known. The only other known population in the Sierra Madre Occidental, at Ejido Ojo de Agua El Cazador, has shown decrease numbers through time because its status is highly precarious (JHMG, JN). Actually, this species is endangered and endemic to Mexico, it is important to note the phenology of the observations recorded at this site. Male SMSP were singing from the grass spikes and displaying territorial behavior. The pursuits in mid-air and occasional fights that we observed are evidence of breeding activity (Fig. 2). In addition, support for our conclusion is based on the date of this discovery: 10 June 2016. This new locality here described in the state of Durango is only $64.5 \mathrm{~km}$ to the north of the other known Durango locality of Ejido Ojo de Agua El Cazador, so it is possible that birds from this site could move to this new locality with habitat available to reproduce.

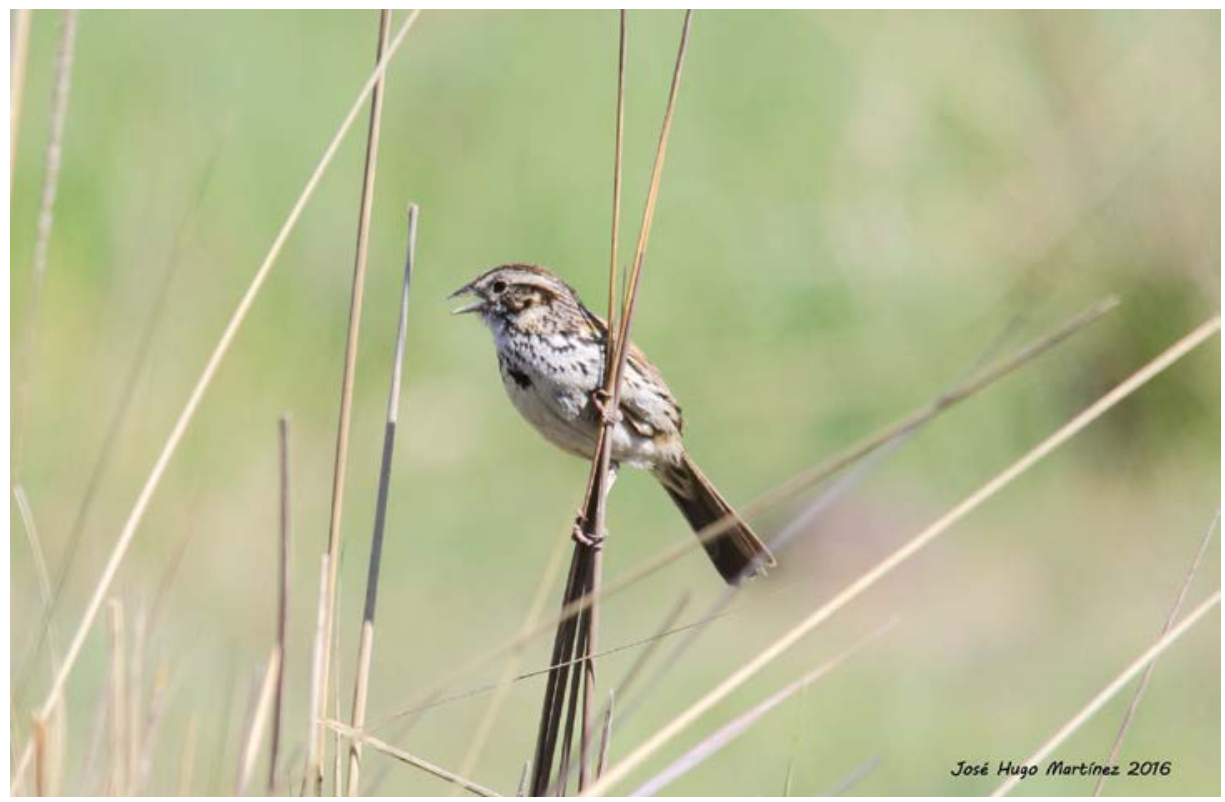

Figure 2. Sierra Madre Sparrow (Xenospiza baileyi) singing at "El Bajío la Cantera", San Dimas Municipality, Durango, México.

A recent genetic analysis found, that allopatric populations from the two known distribution ranges show the absence of significant phyleographic structure, which indicates the origin of SMPS had a single existing lineage, and a marked haplotypic differentiation among the populations as well that shows a high degree of isolation, mainly in the population of Durango (Oliveras de Ita et al., 2012). Limited gene flow owing to fragmented habitat and widely unconnected ranges suggest that the best management option would be to translocate SMSP from southern populations to the northern one in Durango (Oliveras de Ita et al., 2012).

The translocation of birds from the south would not be necessary as this new discovered population is larger and with better habitat condition than the population formally breeding at Ejido Ojo de Agua El Cazador (JHMG, JN, personal records). It is quite important to remark that, the population at Ejido Ojo de Agua El Cazador has dwindled in recent years even though the inhabitants of the ejido, supported by local authorities and government offices (SEMARNAT, Durango), have made attempts to protect the nesting habitat for the species from overgrazing by fencing with barbed wire the two main nesting areas in $2012(\mathrm{JN})$. We have visited the area and found out that the fenced area is no longer 
present so cattle has been grazing during these past years thus destroying the nesting area which indicates that this short-term strategy did not work.

We also have information from bird watchers (verbally to JHMG), that in recent years there are no records of the SMSP from this locality, which implies serious threats for the protection and conservation of the species. To protect this endangered endemic species of conservation concern (Asaad et al., 2016) and to prevent this new population from following the same path as the one from Ejido Ojo de Agua El Cazador, we will plan a conservation strategy to be presented to local and state authorities based on sound knowledge of the life history of the species, especially those aspects related to their breeding and nesting biology crucial for a better planning of endangered species (Stirnemann et al., 2016), and create with government support a special protection area for the reproductive habitat and the species.

Also, it would be necessary to document its population trend through time as this information can help us to assess if the conservation strategy is working or not and if not, to adequate the management strategy to increase and/or maintain its population size. If successful, we may guarantee its conservation through time as it may be the last healthy population in the state of Durango and the whole Sierra Madre Occidental. In addition to the biological information, needed to start a management strategy for the conservation of the SMSP, it would be crucial to include local inhabitants' perceptions of such strategy as it has been well established that sometimes social factors, including local attitudes and institutional, policy and operational aspects, might have affected conservation efforts (Ainsworth et al., 2016; Assad et al., 2016). In the case of the "El Bajío de la Cantera", which is part of the Ejido 12 de Mayo of the municipality of San Dimas, Durango, local people $(n=270)$ have as main economic activities the forestry, livestock and agriculture (INEGI, 2018), with an area of 10,050 ha (RAN, 2018), where the last two represent a serious threat in the short term for the conservation of the remnants of the bunchgrass that is used as a habitat by the Sierra Madre Sparrow. Also, it will be necessary to recognize the whole area to know and measure other areas with habitat that can be used by birds.

We suggest that any SMSP conservation effort should start by information socialization for all individuals, "ejidatarios", and both local and state authorities, so the possible successful outcome of that strategy would be highly possible.

We think that the area should be recognized under special protection by the federal and state governments, and in turn provide support to the owners so that they receive economical support (subsidies from government programs), so that the Sierra Madre Sparrow habitat will not be altered at least in reproductive season, by cattle grazing. Finally, this population of SMSP should receive in the short term as much attention as possible for its high degree of isolation and demonstrated vulnerability with the population of the Ejido Ojo de Agua del Cazador. The population's status of the Sierra Madre Sparrow of the Sierra Madre Occidental is so critical that it does not resist making more mistakes.

ACKNOWLEDGEMENTS. The authors gratefully acknowledge to reviewers and editors for their valuable comments and contributions to this manuscript.

\section{LITERATURE CITED}

Ainsworth, G. B., Aslin, H. J., Weston, M. A., Garnett, S. T. (2016) Do social values influence levels of conservation effort in threatened species? The case of two Australian chats. Oryx, 50, 636-645.

Assad, I., Lundquist, C., Erdmann, M. V., Costello, M. J. (2016) Ecological criteria to identify areas for biodiversity conservation. Biological Conservation, 213, 309-316. 
Bangs, O. (1931) A new genus and species of American buntings. Proceedings of the New England Zoological Club, 12, 85-88.

Cabrera-García, L., Velázquez-Montes, J. A., Escamilla-Weinmann, M. E. (2006) Identification of priority habitats for conservation of the Sierra Madre Sparrow Xenospiza baileyi in Mexico. Oryx, $40,1-7$.

eBird. (2016) Available at: <http://ebird.org/ebird> (accessed on October 2016).

Gallegos, M. (2014) Sierra Madre Sparrow (Xenospiza baileyi). Neotropical birds online (T. S. Schulenberg, editor). Ithaca: Cornell Laboratory of Ornithology. Available at: <http://neotropical.birds.cornell.edu/portal/species/overview?p_p_spp=656716> (accessed on October 2016).

González-Elizondo, M. S., González-Elizondo, M., Márquez-Linares, M. A. (2007) Vegetación y Ecorregiones de Durango. Plaza y Valdés. México, D.F.

INEGI (Instituto Nacional de Geografía y Estadística) (2018) Durango, núcleos agrarios, tabulados básicos por municipio. En: <http://www3.inegi.org.mx/sistemas/TabuladosBasicos/tabulados/catastro/tbe_dgo.PDF>

IUCN (International Union for the Conservation of Nature) (2018) The IUCN red list of threatened species. Version 2017-3. Available at: <http://www.iucnredlist.org> (accessed on April 2018).

Klicka, J., Spellman, G. M. (2007) A molecular evaluation of the North American "grassland" sparrow clade. The Auk, 124, 537-551.

Klicka, J., Barker, F. K., Burns, K. J., Lanyon, S. M., Lovette, I. J., Chaves, J.A., Bryson, R. W. (2014) A comprehensive multilocus assessment of sparrow (Aves: Passerellidae) relationships. Molecular Phylogenetics and Evolution, 77, 177-182.

Oliveras de Ita, A., Gómez de Silva, H. (2002) Nueva localidad para el gorrión serrano (Xenospiza baileyi). Ornitología Neotropical, 13, 203-204.

Oliveras de Ita, A., Rojas-Soto, O. R. (2006) A survey for the Sierra Madre Sparrow (Xenospiza baileyi), with its rediscovery in the state of Durango, Mexico. Bird Conservation International, $16,25-32$.

Oliveras de Ita, A., Oyama, K., Smith, T. B., Wayne, R. K., Milá, B. (2012) Genetic evidence for recent range fragmentation and severely restricted dispersal in the critically endangered Sierra Madre Sparrow, Xenospiza baileyi. Conservation Genetics, 12, 283-291.

Pitelka, F. A. (1947) Taxonomy and distribution of the Mexican Sparrow Xenospiza baileyi. The Condor, 49, 199-203.

RAN (Registro Agrario Nacional) (2018) Datos abiertos al público de información ejidal. En: $<$ http://datos.ran.gob.mx/conjuntoDatosPublico.php> (accessed on April 2018).

Rojas-Soto, O. R., Martínez-Meyer, E., Navarro-Sigüenza, A. G., Oliveras de Ita, A., Gómez de Silva, H., Peterson, A. T. (2008) Modeling distributions of disjunct populations of the Sierra Madre Sparrow. Journal of Field Ornithology, 79, 245-253.

SEMARNAT (Secretaría de Medio Ambiente y Recursos Naturales) (2010) Norma Oficial Mexicana NOM-059-SEMARNAT -2010, protección ambiental - especies nativas de México de flora y fauna Silvestre -categorías de riesgo y especificaciones para su inclusión, exclusión o cambio-lista de especies en riesgo. Diario Oficial de la Federación, jueves 30 de diciembre de 2010. México, D.F.

Stirnemann, R. L., Potter, M. A., Butler, D., Minot, E. O. (2016) Slow life history traits in an endangered tropical island bird, the Ma'oma'o. Bird Conservation International, 26, 366-379. 